\title{
Fecal collection methods for the determination of protein digestibility in bullfrogs
}

\author{
Métodos de coleta de fezes para determinação da digestibilidade proteica em rã-touro
}

\author{
Marta Verardino De Stéfani ${ }^{{ }^{*}}$ Marcelo Maia Pereira ${ }^{\text {III }}$ Marcio Roberto Reche ${ }^{\mathrm{I}}$ \\ Cleber Fernando Menegasso Mansano ${ }^{I I}$
}

- NOTE -

\section{ABSTRACT}

Adequate methods for the determination of protein digestibility in bullfrogs are important for the understanding of nutrient utilization. Therefore, this study evaluated two methods of feces collection: intestinal dissection and fecal decantation, using cylindric-conical tanks. Frogs were fed with a commercial diet (45\% crude protein) which was ground and supplemented with $0.5 \%$ chromium oxide III. The frogs were fasted $48 \mathrm{~h}$ before force-feeding (5\% of the animal's live weight). For the decantation method, the animals were sacrificed $36 \mathrm{~h}$ after forcefeeding and feces were collected directly from the large intestine. For the sedimentation method, feces were collected when they appeared in the tubes attached to the front end of the cylindric tanks. No significant difference $(P>0.05)$ in the apparent digestibility coefficients of crude protein for dietary was observed between the methods tested $(74.0 \%$ and $76.4 \%$ for the dissection and decantation methods, respectively). In conclusion, both methods can be used for the determination of protein digestibility of bullfrog feeds.

Key words: protein digestibility coefficient, methodology, nutrition, frog farming.

\section{RESUMO}

A avaliação de metodologias adequadas para a determinação da digestibilidade proteica em rã-touro é de grande importância para o entendimento do aproveitamento dos nutrientes. Neste estudo, foram avaliados dois métodos de coleta de fezes, um por dissecação intestinal e outro por decantação de fezes, utilizando-se aquários de coleta de fezes para peixes. Os animais receberam uma ração comercial (45\% PB), a qual foi moída e adicionado $0,5 \%$ de óxido de crômio III. As rãs permaneceram 48 horas em jejum antes da alimentação forçada (5\% do peso vivo das rãs). No método de dissecação, os animais foram sacrificados 36 horas após a alimentação forçada e as fezes coletadas diretamente do intestino grosso. No método de decantação, as fezes foram coletadas assim que apareciam nos tubos fixados na extremidade anterior dos aquários cilindricos. Verificou-se que não houve diferença significativa $(P>0,05)$ nos coeficientes de digestibilidade aparente da proteina bruta $\left(C D A_{P B}\right)$ da ração entre as metodologias testadas, sendo de $74,0 \%$ e 76,4\%, respectivamente, para o método de dissecação e decantação. Concluiu-se que ambas as metodologias podem ser utilizadas para a determinação da digestibilidade proteica de alimentos para rã-touro.

Palavras-chave: coeficiente de digestibilidade da proteina, metodologias, nutrição, ranicultura.

Frog farming is an activity that occupies a relatively small physical space and represents a good economic alternative (SEIXAS FILHO et al., 2010). As is the case of any aquatic organism, an adequate diet is essential for the growth of the bullfrogs and the amount spent on food contributes to total production costs (DIAS et al., 2007).

Bullfrogs have a complex life cycle that consists of two distinct phases with different dietary habits: the tadpole stage is omnivorous (SCHIESARI et al., 2009), whereas adult frogs after metamorphosis have a carnivorous diet (SECOR, 2009). In the 1980s, a diet intercropped with Musca domestica larvae was introduced for the feeding of post-metamorphic bullfrogs (ÁLVAREZ \& REAL, 2006). At present, balanced commercial diets for carnivorous fish are used (FENERICK Jr \& STÉFANI, 2005).

'Faculdade de Ciências Agrárias e Veterinária, Universidade Estadual Paulista (UNESP), Via de acesso Prof. Paulo D. Castellane, s/n, 14884-900, Jaboticabal, SP, Brasil. E-mail: martavs@fcav.unesp.br. .Corresponding author.

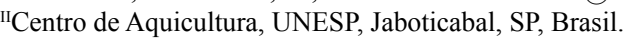

IIIFundação Instituto de Pesca do Estado do Rio de Janeiro, Niterói, RJ, Brasil. 
The elaboration of a diet that meets the nutritional needs of animals requires knowledge about the digestibility of foods (FURUYA, 2010), which is defined as the part of a food or nutrient that disappears through absorption in the digestive tract and is not present in feces (SAKOMURA \& ROSTAGNO, 2007). Digestibility assays have determined the metabolizable energy of some foods using the method of force-feeding and combined collection of total feces and water in the boxes in which the animals were kept (CASTRO et al., 2001; RODRIGUES et al., 2004). Within this context, MOURIÑO \& STÉFANI (2006) evaluated four fecal collection methods for the determination of protein digestibility of bullfrog feeds and found that fecal decantation was the most indicated.

The objective of the present study was to improve the fecal collection methods (dissection and decantation) in bullfrogs.

The experiment was conducted at the Aquaculture Center of São Paulo State University (Caunesp), Jaboticabal, São Paulo, Brazil. Ninetysix bullfrogs (Lithobates catesbeianus Shaw, 1802) weighing 180 to $200 \mathrm{~g}$ (mean: $190.0 \pm 4.3 \mathrm{~g}$ ) were allocated to 16 plastic boxes measuring 46 (height) x 30 (width) x $9 \mathrm{~cm}$ (depth). The lid of the box permitted the circulation of air inside the system and containment of the animals. The boxes were filled with approximately $300 \mathrm{ml}$ of water to permit hydration and thermoregulation of the frogs. The boxes were mounted with a slight inclination to guarantee that two-thirds of the bottom was dry and the other part was filled with water.

The animals were fasted for $48 \mathrm{~h}$ for adaptation to the environment and emptying of the digestive tract (BRAGA et al., 1998). After fasting, the animals were fed with an extruded commercial diet (45\% crude protein) which was ground and supplemented with $0.5 \%$ chromium oxide III as an indicator. Force-feeding as proposed by BRAGA et al. (1998) was used for animal feeding, at a proportion of $5 \%$ of the animal's live weight.

For fecal collection by intestinal dissection, 48 bullfrogs were desensitized and the bone marrow was sectioned $36 \mathrm{~h}$ after force-feeding. This interval had been determined in a previous assay showing the presence of feces in the final part of the gastrointestinal tract after this period. For collection of feces from the large intestine, the abdominal cavity of the frog was opened with scissors. Next, the anterior and posterior ends of the large intestine were ligated with nylon thread, cut, and placed in a freezer for $30 \mathrm{~min}$. After freezing, the wall of the intestine was cut and feces were collected with a spatula to prevent their contamination with intestinal mucosa. The fecal material was stored in identified plastic containers in a freezer. Next, the fecal samples were dried in an oven with forced air circulation at $55^{\circ} \mathrm{C}$ until a constant weight was obtained and then ground for the determination of crude protein content by the micro-Kjeldahl method (A.O.A.C., 1995).

For fecal collection by the decantation method, eight cylindric glass fiber tanks with a capacity of $80 \mathrm{~L}$ and conical bottom were used. The water column in the tank only reached the conical parts and a screen support was mounted so that the animals would not drown and keep hydrated. In addition, a water circulation system was adapted to prevent the accumulation of endogenous material from the animals. A Falcon plastic tube and ball valve were placed at the lower end of the tank.

For the experiment, 48 bullfrogs were transferred to the cylindric tanks (6 frogs/tank) $36 \mathrm{~h}$ after force-feeding. The fecal material that settled in the plastic tube was collected immediately after appearance over a period of $8 \mathrm{~h}$ to reduce as much as possible nutrient leaching and deposition of endogenous material. For this purpose, the valve of the tank was closed and the plastic tube containing the fecal material was removed. Next, excess water was removed and the feces samples were dried in an oven with forced air circulation at $55^{\circ} \mathrm{C}$ until a constant weight was obtained for the determination of crude protein content.

For the two methods, the chromium oxide content of feces and feed was measured by the nitric acid-perchloric acid digestion method as described by FURUKAWA \& TSUKAHARA (1966). The apparent digestibility coefficient of crude protein $\left(\mathrm{ADC}_{\mathrm{CP}}\right)$ was estimated using the equation of NOSE (1966):

$\mathrm{ADC}=100-100 \times \frac{\% \text { indicator in feed })}{\% \text { indicator in feces })} \times \frac{\% \text { nutrient in feces })}{\% \text { nutrient in feed })}$

The $\mathrm{ADC}_{\mathrm{CP}}$ values obtained with each method were used for the evaluation of the two fecal collection methods. A completely randomized experimental design consisting of two treatments and eight repetitions (tanks) was used. Treatment means were submitted to analysis of variance (SAS, 2008).

No significant difference $(\mathrm{P}>0.05)$ in mean $\mathrm{ADC}_{\mathrm{CP}}$ values was observed between fecal collection by intestinal dissection (74.0\%) and decantation (76.4\%). These results indicate the absence of nutrient leaching in the decantation method when feces are collected immediately. Therefore, both methods can be used safely for the determination of protein digestibility of bullfrog feeds. 
These results differ from those reported by MOURIÑO \& STÉFANI (2006) who observed significantly higher $\mathrm{ADC}_{\mathrm{CP}}$ for the decantation method when compared to intestinal dissection. This finding might be explained by the occurrence of nutrient leaching since the fecal samples in the decantation method were collected at intervals of $4 \mathrm{~h}$. In contrast, in the present study the fecal samples were collected as soon as they appeared. In addition, water circulation inside the tanks prevented contamination of feces with skin and/or endogenous material, a fact yielding more precise results.

KITAGIMA \& FRACALOSSI (2010) compared the Guelph and dissection methods for the determination of nutrient digestibility and evaluation of commercial feeds for channel catfish and observed no significant differences between the two methods. Similar results have been reported by VENERO et al. (2007) who compared the same methods in sturgeon, in agreement with the present results.

The intestinal dissection method can underestimate the results if the intestine is squeezed during feces removal, causing contamination with urine and intestinal mucosa (MOURIÑO \& STÉFANI, 2006). The pressure applied during dissection may cause damage to the viscera and consequent fecal contamination with endogenous nitrogen from mucus and epithelial cells, reducing digestibility (HAJEN et al., 1993). This fact can be ruled out in the present study since feces were removed with a spatula after freezing of the intestine, preventing squeezing and consequent contamination with endogenous nitrogen.

The methods tested have advantages and disadvantages. The advantages of the intestinal dissection method include the easy collection and drying of fecal samples, knowledge of the amount of feces collected, and shorter duration of fecal collection. The disadvantage is that the animal needs to be sacrificed. The advantage of the decantation method using tanks is that the animal does not need to be sacrificed. However, disadvantages are the greater difficulty in knowing the exact amount of collected feces due to the large amount of water present and the consequent difficulty in drying the fecal samples. In addition, this method is time consuming since the fecal samples have to be collected as soon as they appear in the plastic tube to prevent nutrient leaching and collection needs to be continued over a minimum period of $8 \mathrm{~h}$ in order to obtain a sufficient amount of material for subsequent analysis.

The present results showed that the modification of the methods tested were adequate, i.e., for the dissection method, fecal samples should be removed without squeezing to avoid contamination with endogenous nitrogen from mucus and epithelial cells, which would underestimate digestibility. In the decantation method, the fecal collection tanks need a water circulation system and feces should be collected immediately to prevent nutrient leaching and the consequent overestimation of digestibility. In conclusion, both fecal collection methods can be used safely for the determination of protein digestibility of bullfrog feeds.

\section{ACKNOWLEDGEMENTS}

The financial support of Fundação de Amparo à Pesquisa do Estado de São Paulo (FAPESP) is acknowledged.

\section{ETHICS COMMITTEE AND BIOSECURITY}

The study was approved by the Ethics Committee on Animal Use (CEUA) of the Faculdade de Ciências Agrárias e Veterinárias, UNESP (Permit $N^{\circ}$. 023922/06) and was conducted according to the ethical guidelines of the Brazilian College of Animal Experimentation (COBEA).

\section{REFERENCES}

ÁLVAREZ, R.; REAL, M. Significance of initial weight of post-metamorphosis froglets for growth and fattening of Rana perezi Seoane, 1885, raised in captivity. Aquaculture, v.255, p.429-435, 2006. Available from: <http://dx.doi.org/10.1016/j. aquaculture.2005.12.026>. Accessed: Ago. 10, 2014. doi: 10.1016/j.aquaculture.2005.12.026.

ASSOCIATION of OFFICIAL ANALYTICAL CHEMISTRY (AOAC). Official methods of analysis. 16.ed. Arlington: Patricia Cunnif, 1995. 1025p.

BRAGA, L.G.T. et al. Valor nutritivo de alguns alimentos para rãtouro (Rana catesbeiana, Shaw 1802) na fase de recria. Revista Brasileira de Zootecnia, v.27, p.203-209, 1998.

CASTRO, J.C. et al. Valor nutritivo de alguns alimentos para rãs. Revista Brasileira de Zootecnia, v.30, p.605-610, 2001. Available from: <http://dx.doi.org/10.1590/S151635982001000300001>. Accessed: Ago. 10, 2014. doi: 10.1590/ S1516-35982001000300001

DIAS, D.C. et al. Estudo da viabilidade econômica do uso de probiótico na alimentação da rã-touro, Rana catesbeiana. Informações Econômicas, v.37, p.1-13, 2007.

FENERICK JUNIOR, J.; STÉFANI, M.V. Desempenho e parâmetros metabólicos de rã-touro, Rana catesbeiana, alimentada com diferentes rações comerciais. Acta Scientiarm Animal Science, v.27, p.377-382, 2005. Available from: $<\mathrm{http}: / / \mathrm{dx}$.doi. org/10.4025/actascianimsci.v27i3.1214>. Accessed: Ago. 20, 2014. doi: $10.4025 /$ actascianimsci. v27i3.1214.

FURUKAWA, A.A.; TSUKAHARA, H. On the acid digestion for the determination of chromium oxide as index substance in the study of digestibility of fish feed. Bulletin of the Japanese Society of Scientific Fisheries, v.32, p.502-506, 1966. 
FURUYA, W.M. Tabelas brasileiras para nutrição de tilápias. Toledo: GFM, 2010. 100p.

HAJEN, W.E. et al. Digestibility of various feedstuffs by postjuvenile Chinook salmon (Oncorhychus tshawytscha) in sea water. 1. Validation of technique. Aquaculture, v.112, p.321-332, 1993. Available from: <http://www.sciencedirect.com/science/ article/pii/ 004484869390393D $>$. Accessed: Jul. 30, 2014. doi: 10.1016/0044-8486(93)90393-D.

KITAGIMA, R.E.; FRACALOSSI, D.M. Validation of a methodology for measuring nutrient digestibility and evaluation of commercial feeds for channel catfish. Scientia Agrícola, v.67, p.611-615, 2010. Available from: <http://dx.doi.org/10.1590/ S0103-90162010000500016>. Accessed: Ago. 01, 2014. doi: 10.1590/S0103-90162010000500016.

MOURIÑO, J.L.P.; STÉFANI, M.V. Avaliação de métodos de coleta de fezes para determinação da digestibilidade protéica em rã-touro (Rana catesbeiana). Ciência Rural, v.36, p.954958, 2006. Available from: <http://dx.doi.org/10.1590/S010384782006000300035>. Accessed: Ago. 10, 2014. doi: 10.1590/ S0103-84782006000300035.

NOSE, T. Recent advances in the study of fish digestion in Japan. In: SYMPOSIUM ON FINFISH NUTRITION AND FISH FEED TECHNOLOGY, 1966, Belgrade. Proceedings... Belgrade: EIFAC/FAO, 1966. 15p.

RODRIGUES, M.L. et al. Determinação da energia metabolizável de alguns alimentos para rã-touro (Rana catesbeiana). Boletim do Instituto de Pesca, v.30, p.147-154, 2004.
SAKOMURA, N.K.; ROSTAGNO, H.S. Métodos de pesquisa em nutrição de monogástricos. Jaboticabal: FUNEP, 2007. 283p.

SAS Institute. SAS/STAT 9.2. User's guide. Cary, NC, 2008. 1 CD.

SCHIESARI, L. et al. Carnivore and resource-based niche differentiation in anuran larvae: implications for food web and experimental ecology. Freshwater Biology, v.54, p.572586, 2009. Available from: <http://onlinelibrary.wiley.com/ doi/10.1111/j.1365-2427.2008.02134.x/pdf>. Accessed: Ago. 10, 2014. doi: 10.1111/j.1365-2427.2008.02134.x.

SECOR, S.M. Specific dynamic action: a review of the postprandial metabolic response. Journal of Comparative Physiology B, v.179, p.1-56, 2009. Available from: <http://download.springer.com/static/ pdf $/ 764 /$ art $\% 253$ A $10.1007 \% 252$ Fs00360-008-0283-7.pdf?auth66 $=1410443680 \_962208 \mathrm{~b} 3688 \mathrm{~d} 6 \mathrm{c} 6727 \mathrm{ee} 41 \mathrm{e} 13 \mathrm{c} 1 \mathrm{caf} 90 \& \mathrm{ext}=. \mathrm{pdf}>$. Accessed: Jul. 29, 2014. doi: 10.1007/s00360-008-0283-7.

SEIXAS FILHO, J.T. et al. Desempenho de girinos de rãtouro alimentados com ração comercial contendo diferentes concentrações de proteína bruta. Revista Brasileira de Ciências Agrárias, v.5, p.428-433, 2010. Available from: <http://www. redalyc.org/pdf/1190/119016971024.pdf>. Accessed: Jul. 20, 2014. doi: 10.5039/agraria.v5i3a788.

VENERO, J.A. et al. Validation of a fecal collection method for determination of apparent digestibility coefficients of diets in Gulf of Mexico sturgeon. North American Journal of Aquaculture, v.69, p.90-94, 2007. Available from: <http://dx.doi.org/10. 1577/ A05-084.1>. Accessed: Ago. 11, 2014. doi: 10.1577/A05-084.1. 